\title{
Pengaruh Model Pembelajaran Snowball Throwing Berbasis Penilaian Kinerja Terhadap Hasil Belajar IPA
}

\author{
Kadek Sutiani ${ }^{*}$, Ni Ketut Suarni², I Ketut Dibia ${ }^{3}$ \\ 1,2 Jurusan Pendidikan Guru Sekolah Dasar, Fakultas Ilmu Pendidikan, Universitas Pendidikan Ganesha Singaraja, Indonesia \\ 3 Jurusan Bimbingan Konseling, Fakultas Ilmu Pendidikan, Universitas Pendidikan Ganesha Singaraja, Indonesia
}

\author{
A R T I C L E I N \\ $\mathrm{FO}$ \\ Article history: \\ Received 17 May \\ 2018 \\ Received in revised \\ form \\ 12 June 2018 \\ Accepted 18 July \\ 2018 \\ Available online 19 \\ August 2018 \\ Kata Kunci: \\ snowball throwing, \\ penilaian kinerja, \\ hasil belajar \\ Keywords: \\ snowball throwing, \\ performance \\ assessment, \\ learning result
}

\begin{abstract}
A B STRAK
Permasalahan dalam penelitian ini adalah rendahnya hasil belajar IPA siswa kelas IV SD. Penelitian ini bertujuan untuk mengetahui pengaruh model pembelajaran snowball throwing berbasis penilaian kinerja terhadap hasil belajar IPA. Penelitian ini adalah penelitian eksperimen semu dengan desain non-equivalent post test only control group design. Populasi penelitian adalah siswa kelas IV di SD gugus 1 Kecamatan Sukasada Kabupaten Buleleng Tahun Pelajaran 2017/2018. Sebanyak 55 siswa dipilih sebagai sampel penelitian yang ditentukan melalui simple random sampling. Data yang dianalisis dalam penelitian ini adalah hasil belajar IPA ranah kognitif yang dikumpulkan dengan tes pilihan ganda. Data dianalisis dengan statistik deskriptif dan statistik inferensial (uji-t polled varians). Hasil uji-t, menunjukkan $t_{\text {hitung }}=8,57$ dan $t_{\text {tabel }}=2,005$ (pada taraf signifikansi $5 \%$ ). Berdasarkan kriteria pengujian, $t_{\text {hitung }}>t_{\text {tabel }}(8,57>2,005)$, maka $\mathrm{H}_{0}$ ditolak dan $\mathrm{H}_{1}$ diterima. Maka dari itu, dapat disimpulkan bahwa model pembelajaran snowball throwing berbasis penilaian kinerja berpengaruh positif terhadap hasil belajar IPA siswa kelas IV di SD Gugus 1 Kecamatan Sukasada Kabupaten Buleleng.
\end{abstract}

\section{A B S T R A C T}

The problem in this research is low learning result in science subject of the fourth grade students. This research aims at to find out the effect of snowball throwing learning model based on performance assessment toward science learning result. This research was quasi-experiment research with non-equivalent post-test only control group design. The population was fourth grade students of SD Gugus 1 Sukasada district Buleleng regency in Academic Year 2017/2018. There were 55 students were selected as the research samples determined by simple random sampling. The data analyzed in this research was the result of science learning cognitive which were collected by multiple choice test. The data was analyzed by descriptive statistics and inferential statistics (t-test polled variants). The result of $t$-test shows that $t_{\text {value }}=8,57$ and $t_{\text {table }}=2,005$ (at significance level $5 \%$ ). Based on the test criteria, $t_{\text {value }}>t_{\text {table }}(8.57>2.005)$, then $\mathrm{H}_{0}$ is rejected and $\mathrm{H}_{1}$ is accepted. Therefore, it can be concluded that snowball throwing learning model based on performance assessment has a positive effect towards the results of science learning in fourth grade students of SD Gugus 1 Sukasada district Buleleng regency.

\footnotetext{
* Corresponding author.

E-mail addresses: kadek.sutiani@yahoo.com (Kadek Sutiani)
} 


\section{Pendahuluan}

IPTEK (Ilmu Pengetahuan dan Teknologi) berkembang secara pesat sehingga menuntut kesiapan untuk bersaing secara global. Perkembangan IPTEK ini menjadi tantangan besar bagi suatu bangsa untuk menciptakan sumber daya manusia yang berkualitas. Terciptanya sumber daya manusia yang berkualitas akan menjamin keberlangsungan pembangunan suatu bangsa. Oleh karena itu, peningkatan kualitas sumber daya manusia harus dilaksanakan sejak dini melalui pendidikan.

Pendidikan yang berkualitas akan menghasilkan sumber daya manusia yang berkualitas. Semakin tinggi kualitas pendidikan serta kualitas sumber daya manusia di suatu bangsa, maka semakin besar peluang suatu bangsa untuk mampu bersaing dan menunjukkan eksistensinya dalam skala internasional. Hal ini akan berimbas pada keberlangsungan pembangunan suatu bangsa menjadi lebih maju.

Pendidikan merupakan kegiatan yang berlangsung sesuai dengan tuntutan dan perkembangan zaman untuk membentuk siswa yang unggul secara kognitif, afektif, serta psikomotorik. Susanto (2016:85) menyatakan bahwa "pendidikan adalah upaya yang terorganisasi, berencana dan berlangsung secara terus-menerus sepanjang hayat untuk membina anak didik menjadi manusia paripurna, dewasa, dan berbudaya". Sedangkan, Undang-undang No. 20 tahun 2003 tentang Sistem Pendidikan Nasional menyatakan, pendidikan adalah usaha sadar dan terencana untuk mewujudkan suasana belajar dan proses pembelajaran agar peserta didik secara aktif mengembangkan potensi dirinya untuk memiliki kekuatan spiritual keagamaan, pengendalian diri, kepribadian, kecerdasan, akhlak mulia, serta keterampilan yang diperlukan dirinya, masyarakat, bangsa dan Negara.

Berdasarkan definisi di atas, pada dasarnya pendidikan adalah kegiatan terencana yang dilakukan sepanjang hayat untuk membentuk manusia cerdas secara kognitif, afektif, serta psikomotorik dan berguna bagi dirinya maupun lingkungannya.

Pendidikan memiliki tujuan yang harus dicapai. Dewey (dalam Sukardjo dan Komarudin, 2013:14) menyatakan, tujuan pendidikan ialah mengembangkan seluruh potensi yang dimiliki oleh peserta didik sehingga dapat berfungsi secara individual dan berfungsi sebagai anggota masyarakat melalui penyelenggaraan pendidikan dan pengajaran yang bersifat aktif, ilmiah, dan memasyarakatkan serta berdasarkan kehidupan nyata yang dapat mengembangkan jiwa, pengetahuan, rasa tanggung jawab, keterampilan, kemauan, dan kehalusan budi pekerti.

Sedangkan Undang-undang No. 20 tahun 2003 Pasal 3 menyatakan, pendidikan nasional berfungsi mengembangkan kemampuan dan membentuk watak serta peradaban bangsa yang bermartabat dalam rangka mencerdaskan kehidupan bangsa, bertujuan untuk berkembangnya potensi peserta didik agar menjadi manusia yang beriman dan bertakwa kepada Tuhan Yang Maha Esa, berakhlak mulia, sehat, berilmu, cakap, kreatif, mandiri, dan menjadi warga negara yang demokratis serta bertanggung jawab.

Berdasarkan pernyataan di atas, pada dasarnya tujuan pendidikan adalah untuk mengembangkan seluruh potensi siswa menjadi manusia seutuhnya agar mampu menghadapi setiap perubahan yang terjadi sesuai tuntutan zaman. Tercapainya tujuan pendidikan nasional dapat dilakukan melalui berbagai jenjang pendidikan khususnya SD.

SD merupakan jenjang pendidikan dasar pertama yang diperoleh siswa. Pada jenjang ini, dilaksanakan peletakan dasar-dasar keilmuan yang merupakan pondasi dari jenjang pendidikan selanjutnya. Mutu pendidikan pada jenjang yang lebih tinggi sangat ditentukan oleh kualitas pendidikan dasar yang diperoleh. Hal tersebut sejalan dengan pendapat Susanto (2016:92) yang menyatakan bahwa "mutu pendidikan menengah dan pendidikan tinggi tergantung kepada dasar kemampuan dan keterampilan yang dikembangkan sejak tingkat sekolah dasar". Faktor yang berperan penting dalam mengembangkan kemampuan dan keterampilan dasar siswa guna meningkatkan mutu pendidikan adalah guru.

Guru merupakan ujung tombak keberhasilan pendidikan yang bertugas mendidik, mengajar, dan melatih. Mendidik berarti meneruskan dan mengembangkan nilai-nilai hidup dan kehidupan. Mengajar berarti meneruskan, mewariskan, menanamkan dan mengembangkan ilmu pengetahuan dan teknologi. Melatih berarti mengembangkan keterampilan-keterampilan pada siswa (Husien 2017:67). Guru memerlukan inovasi-inovasi dalam kegiatan pembelajaran agar proses pembelajaran berjalan secara kondusif sehingga akan terwujud suasana belajar yang aktif, interaktif, dan menyenangkan. Melalui proses pembelajaran yang seperti ini, siswa akan mengkonstruksi pengetahuannya sendiri dalam kegiatan yang menyenangkan dan interaktif sehingga pembelajaran akan lebih bermakna.

Kualitas hasil belajar dan mutu pendidikan dapat ditingkatkan dengan cara merancang pembelajaran yang bermakna. Pembelajaran yang seperti ini lebih banyak melibatkan siswa secara langsung. Sehingga fokus pembelajaran bukan lagi ada pada guru, tetapi pada siswa. Pembelajaran ini dapat dirancang oleh guru di setiap mata pelajaran. Salah satunya adalah pada mata pelajaran IPA. 
IPA merupakan salah satu diantara 5 (lima) mata pelajaran pokok yang diajarkan pada setiap jenjang pendidikan, termasuk jenjang SD. Agustiana dan Tika (2013:257) menyatakan, "pembelajaran IPA pada jenjang pendidikan dasar harus mampu membekali siswa dengan seperangkat kompetensi dan keterampilan serta nilai yang dibutuhkan oleh mereka untuk mengenal diri, lingkungan, dan tantangan masa depan yang akan dihadapi". Selanjutnya, Widiana (2016:826) menyatakan, "pembelajaran IPA di sekolah dasar memegang peranan penting dalam pembelajaran IPA di jenjang-jenjang berikutnya sebab pengetahuan awal siswa sangat berpengaruh pada minat dan kecenderungan siswa untuk belajar IPA". Berdasarkan pendapat tersebut, dapat dimaknai bahwa, pembelajaran IPA di SD harus menekankan pada proses penemuan langsung agar siswa mampu mengenal diri dan lingkungannya secara nyata, serta tantangan masa depan yang akan dihadapinya. Proses penemuan langsung tersebut dapat dilaksanakan melalui pembelajaran yang menyenangkan, sehingga siswa akan memiliki minat yang tinggi untuk belajar IPA pada setiap jenjang pendidikan yang ditempuhnya.

Pembelajaran IPA di sekolah masih belum sesuai dengan harapan. Hal tersebut didukung oleh hasil wawancara, observasi, dan pencatatan dokumen mengenai pembelajaran IPA yang dilakukan pada guruguru kelas IV di SD gugus 1 Kecamatan Sukasada Kabupaten Buleleng Tahun Pelajaran 2017/2018.

Berdasarkan hasil wawancara pada tanggal 23 dan 24 November 2017, guru-guru menyatakan sebagai berikut. Pertama, motivasi sebagian besar siswa untuk belajar IPA masih rendah. Pada proses pembelajaran IPA, hanya beberapa siswa yang aktif dan sebagian besar siswa lainnya masih pasif. Kedua, instrumen yang digunakan untuk mengukur hasil belajar IPA adalah tes. Guru tidak melakukan penilaian untuk kinerja siswa selama proses pembelajaran. Ketiga, guru sangat jarang menggunakan model pembelajaran dan lebih sering menggunakan metode ceramah, tanya jawab, dan penugasan. Hal tersebut disebabkan oleh kurangnya pemahaman guru mengenai penggunaan model pembelajaran.

Selain melakukan wawancara dengan guru-guru kelas IV, dilakukan observasi pada tanggal 24 dan 25 November 2017 untuk melihat proses pembelajaran IPA yang dilaksanakan oleh guru di dalam kelas. Hasil observasi yang diperoleh adalah sebagai berikut. Pertama, pembelajaran IPA masih berpusat pada guru. Pada proses pembelajaran, guru lebih sering menjelaskan materi pelajaran daripada memberikan kesempatan kepada siswa untuk membangun pengetahuannya sendiri. Kedua, guru tidak memberikan penghargaan terhadap kinerja yang ditunjukkan oleh siswa selama proses pembelajaran IPA. Hal tersebut menyebabkan rendahnya antusias siswa untuk belajar IPA. Ketiga, guru belum menerapkan model pembelajaran yang inovatif sehingga sebagian besar siswa merasa bosan dan pasif selama mengikuti pembelajaran IPA.

Melengkapi hasil wawancara dan observasi, maka dilaksanakan pencatatan dokumen untuk nilai UAS IPA kelas IV di SD Gugus 1 Kecamatan Sukasada. Rincian nilai UAS IPA ditunjukkan pada pada tabel 1 berikut.

Tabel 1. Rata-Rata Nilai UAS Semester 1 Siswa Kelas IV di SD Gugus 1 Kecamatan Sukasada Kabupaten Buleleng

\begin{tabular}{|c|c|c|c|c|}
\hline No. & Nama Sekolah & Jumlah Siswa & $\begin{array}{c}\text { Rata-Rata Nilai } \\
\text { UAS }\end{array}$ & KKM \\
\hline 1 & SD 1 Pancasari & & K13 & \\
\hline 2 & SD 3 Pancasari & & K13 & \\
\hline 3 & SD 4 Pancasari & 22 & 56,5 & 62 \\
\hline 4 & SD 1 Wanagiri & & K13 & \\
\hline 5 & SD 2 Wanagiri & 33 & 58,9 & 64 \\
\hline 6 & SD 3 Wanagiri & 12 & 62,3 & 65 \\
\hline 7 & SD 4 Wanagiri & 7 & 61,3 & 65 \\
\hline 8 & SD 3 Tegallinggah & 16 & 66,2 & 70 \\
\hline
\end{tabular}

Berdasarkan tabel di atas, maka dapat diketahui bahwa nilai rata-rata UAS IPA siswa kelas IV di SD Gugus 1 Kecamatan Sukasada lebih rendah daripada KKM (Kriteria Ketuntasan Minimal) yang telah ditentukan. Tinggi rendahnya hasil belajar siswa dipengaruhi oleh faktor-faktor tertentu.

Faktor yang memengaruhi perolehan hasil belajar siswa adalah faktor internal dan faktor eksternal. Tim MKDP (2013:141) menyatakan bahwa faktor-faktor tersebut dapat berinteraksi secara langsung ataupun tidak langsung dalam proses pembelajaran karena adanya faktor-faktor tertentu yang memengaruhi prestasi belajar yaitu motivasi berprestasi, intelegensi, dan kecemasan. Untuk meningkatkan hasil belajar siswa, guru harus memerhatikan motivasi berprestasi, intelegensi, serta kecemasan yang mungkin dialami siswa selama proses pembelajaran. Maka dari itu, diperlukan inovasi dalam pembelajaran IPA untuk menghilangkan kecemasan serta meningkatkan motivasi berprestasi, 
intelegensi, dan hasil belajar siswa. Salah satu inovasi yang dapat dilakukan adalah dengan menerapkan model pembelajaran snowball throwing dalam pembelajaran IPA.

Wirawan (2014) menyatakan snowball throwing merupakan salah satu model pembelajaran kooperatif yang melatih siswa agar lebih tanggap menerima informasi dari siswa lain dalam bentuk bola saju yang terbuat dari kertas, dan menyampaikan informasi tersebut kepada anggota kelompoknya. Herrmann (2013) menyatakan bahwa pembelajaran kooperatif berkaitan dengan penyusunan interaksii siswa dengan cara yang cenderung mampu meningkatkan ketergantungan siswa dengan siswa lainnya secara positif serta meningkatkan interaksi antar siswa dalam memecahkan permasalahan untuk memahami materi pelajaran. Selanjutnya Shoimin (2014:174) menyatakan bahwa dengan penerapan model ini, diskusi kelompok dan interaksi antar siswa dari kelompok yang berbeda memungkinkan terjadinya saling berbagi pengetahuan dan pengalaman dalam upaya menyelesaikan permasalahan yang mungkin timbul dalam diskusi yang berlangsung secara lebih interaktif dan menyenangkan. Berdasarkan pendapat ahli tersebut, pada dasarnya melalui penerapan model snowball throwing, proses pembelajaran di kelas akan berlangsung secara interaktif dan menyenangkan. Kecemasan yang mungkin timbul dalam diri siswa akan berkurang karena proses pembelajaran yang menyenangkan dan hal tersebut akan berpengaruh positif terhadap hasil belajar siswa.

Proses pembelajaran IPA menggunakan model pembelajaran snowball throwing dapat dipadukan dengan penilaian yang mendukung kinerja siswa selama proses pembelajaran berlangsung. Salah satu penilaian yang dapat digunakan dalam pembelajaran IPA adalah penilaian kinerja. Arhin (2015) menyatakan, "penilaian kinerja adalah jenis penilaian yang mengharuskan siswa untuk menunjukkan bahwa mereka memiliki penguasaan keterampilan dan kompetensi tertentu dengan melakukan suatu kegiatan untuk mengungkapkan apa yang mampu mereka lakukan". Keuntungan penggunaan penilaian kinerja menurut Lai (dalam Marhaeni, 2017) adalah sebagai berikut: 1) penilaian kinerja dapat menjadi sebuah proses yang lebih memotivasi siswa, karena siswa menjadi lebih terlibat secara aktif di dalam kelas, 2) guru dapat mengetahui kelemahan siswanya dan dapat mengoreksi verbal kelemahan siswanya secara langsung, dan 3) item pengukuran pada penilaian kinerja dapat menilai kemampuan kognitif dan psikomotorik siswa pada tingkatan yang lebih dibandingkan penilaian tradisional.

Berdasarkan pemaparan masalah di atas, maka perlu dilakukan penelitian yang berjudul "Pengaruh Model Pembelajaran Snowball Throwing Berbasis Penilaian Kinerja Terhadap Hasil Belajar IPA Siswa Kelas IV di SD Gugus 1 Kecamatan Sukasada Kabupaten Buleleng Tahun Pelajaran 2017/2018". Adapun tujuan penelitian ini adalah untuk mengetahui pengaruh model pembelajaran snowball throwing berbasis penilaian kinerja terhadap hasil belajar IPA siswa kelas IV di SD gugus 1 Kecamatan Sukasada Kabupaten Buleleng Tahun Pelajaran 2017/2018.

\section{Metode}

Jenis penelitian ini adalah penelitian eksperimen semu. Desain penelitian yang digunakan dalam penelitian ini adalah non-equivalent post test only control group design. Desain penelitian disajikan pada tabel 2 berikut.

Tabel 2. Rancangan Penelitian Non-Equivalent Post Test Only Control Group Design

\begin{tabular}{lll}
\hline Kelas & Perlakuan & Post-test \\
\hline Eksperimen & $\mathrm{X}$ & $\mathrm{O}_{1}$ \\
Kontrol & - & $\mathrm{O}_{2}$ \\
\hline
\end{tabular}

(dimodifikasi dari Dantes, 2017:17)

Keterangan:

$\mathrm{X} \quad=$ perlakuan model pembelajaran snowball throwing berbasis kinerja

- $\quad=$ = tidak mendapat perlakuan (belajar secara konvensional)

$\mathrm{O}_{1} \quad=$ post test kelompok ekperimen

$\mathrm{O}_{2} \quad=$ post test kelompok kontrol

Penelitian ini dilaksanakan di SD Gugus 1 Kecamatan Sukasada Kabupaten Buleleng pada rentang waktu semester II (genap) tahun pelajaran 2017/2018. Populasi dalam penelitian ini adalah siswa kelas IV Gugus 1 Kecamatan Sukasada Kabupaten Buleleng yang dibelajarkan menggunakan KTSP. Populasi penelitian terdiri dari lima SD, yaitu SD 4 Pancasari, SD 2 Wanagiri, SD 3 Wanagiri, SD 4 Wanagiri, dan SD 3 Tegalinggah dengan jumlah keseluruhan 90 orang siswa.

Untuk mengetahui kesetaraan hasil belajar IPA siswa kelas IV di Gugus 1 Kecamatan Sukasada Kabupaten Buleleng, maka dilakukan uji kesetaraan menggunakan ANAVA satu jalur. Berdasarkan hasil 


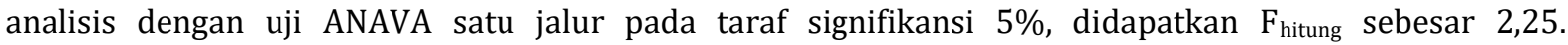
Sedangkan, nilai $F_{\text {tabel }}$ pada taraf signifikansi $5 \%$ dengan $\mathrm{db}_{\mathrm{A}}=4 \mathrm{dan} \mathrm{db}_{\mathrm{dal}}=85$ adalah 2,48 . Hasil perhitungan menunjukkan $\mathrm{H}_{0}$ diterima sedangkan $\mathrm{Ha}$ ditolak karena $\mathrm{F}_{\text {hitung }}<\mathrm{F}_{\text {tabel }}$. Jadi, dapat ditarik kesimpulan bahwa tidak ada perbedaan hasil belajar IPA siswa kelas IV di SD Gugus 1 Kecamatan Sukasada Kabupaten Buleleng Tahun Pelajaran 2017/2018 atau dengan kata lain, hasil belajar IPA siswa kelas IV adalah setara.

Setelah memperoleh hasil uji kesetaraan, maka dilanjutkan dengan penarikan sampel penelitian. Teknik pengambilan sampel yang digunakan dalam penelitian ini adalah simple random sampling. Sampel yang dirandom dalam penelitian ini adalah kelas karena tidak memungkinkan untuk mengubah kelas yang ada. Melalui simple random sampling, diperoleh kelas IV di SDN 4 Pancasari yang berjumlah 22 siswa sebagai kelompok eksperimen dan kelas IV di SDN 2 Wanagiri yang berjumlah 33 siswa sebagai kelompok kontrol. Kelompok eksperimen akan mendapat perlakuan dengan diterapkannya model pembelajaran snowball throwing berbasis penilaian kinerja. Sedangkan, kelompok kontrol belajar secara konvensional.

Data hasil belajar IPA siswa dikumpulkan dengan metode tes dan instrumen yang digunakan adalah tes pilihan ganda yang berjumlah 35 butir soal. Sebelum digunakan, instrumen tersebut diujicobakan ke SDN 1 Wanagiri, SDN 3 Wanagiri, SDN 4 Wanagiri, dan SDN 3 Tegallinggah dengan jumlah keseluruhan siswa adalah 57 orang. Hasil uji coba tersebut digunakan untuk menghitung uji validitas, tingkat kesukaran, daya beda, dan reliabilitas instrumen. Berdasarkan hasil perhitungan, diperoleh 30 butir soal yang dapat digunakan dari 35 butir soal yang telah diujicobakan.

Analisis data yang digunakan dalam penelitian ini yaitu analisis statistik deskriptif dan statistik inferensial. Analisis statistik deskriptif digunakan untuk mengitung tinggi rendahya kualitas hasil belajar IPA pada siswa yang dibelajarkan dengan model pembelajaran snowball throwing berbasis penilaian kinerja dan siswa yang dibelajarkan dengan model pembelajaran konvensional. Adapun acuan yang digunakan untuk menentukan tinggi rendahya kualitas hasil belajar IPA adalah hasil konversi skor ratarata menggunakan kriteria rata-rata ideal $\left(\mathrm{M}_{\mathrm{i}}\right)$ dan standar deviasi ideal $\left(\mathrm{SD}_{\mathrm{i}}\right)$. Sedangkan analisis statistik inferensial digunakan untuk menganalisis hipotesis penelitian yang diajukan. Adapun teknik yang digunakan untuk menguji hipotesis penelitian adalah uji-t polled varians. Sebelum menganalisis hipotesis penelitian, maka dilakukan uji prasyarat berupa uji normalitas menggunakan uji chi kuadrat dan uji homogenitas varians menggunakan uji F.

\section{Hasil dan Pembahasan}

Data hasil belajar IPA dihitung menggunakan analisis statistik deskriptif untuk menentukan tinggi rendahnya kualitas hasil belajar IPA. Data hasil belajar IPA kelompok eksperimen diperoleh melalui hasil post-test terhadap 22 orang siswa. Berdasarkan post-test, diperoleh skor tertinggi adalah 28 dan skor terendah adalah 15. Hasil perhitungan menggunakan statistik deskriptif terhadap skor hasil belajar IPA kelompok eksperimen menunjukkan rata-rata $($ mean $)=23,13$; median $(\mathrm{Me})=23,50 ;$ modus $(\mathrm{Mo})=25,00$ ; varians $\left(\mathrm{s}^{2}\right)=12,79$; dan standar deviasi $(\mathrm{s})=3,57$. berikut.

Data skor hasil belajar IPA kelompok eksperimen disajikan dalam histogram seperti pada gambar 1

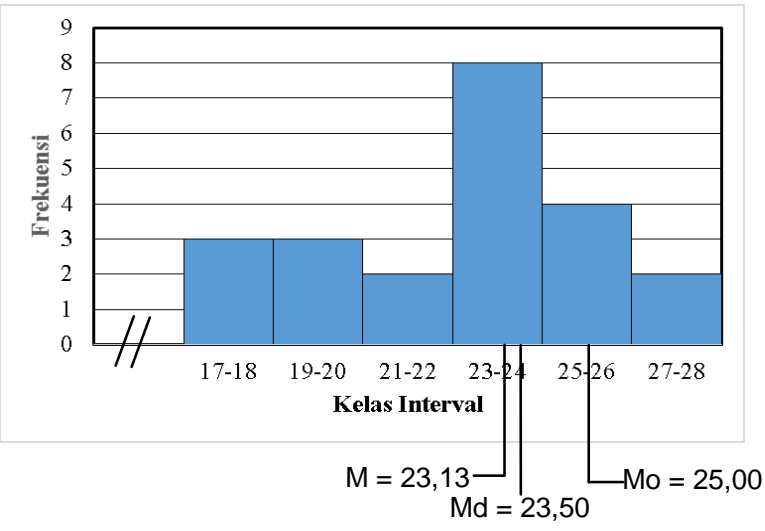

Gambar 1. Histogram Data Hasil Belajar IPA Kelompok Eksperimen

Gambar histogram data hasil belajar IPA kelompok eksperimen di atas menunjukkan bahwa Mo $>$ Md $>$ M. Kualitas variabel hasil belajar IPA kelompok ekperimen dapat diketahui dengan 
mengkonversikan skor rata-rata menggunakan skala penilaian acuan ideal teoretik. Berdasarkan hasil konversi, diperoleh bahwa skor rata-rata hasil belajar IPA kelompok eksperimen dengan $\mathrm{M}=23,13$ tergolong kriteria sangat baik.

Data hasil belajar IPA kelompok kontrol diperoleh melalui hasil post-test terhadap 33 orang siswa. Berdasarkan post-test, diperoleh skor tertinggi adalah 22 dan skor terendah adalah 12 . Hasil perhitungan menggunakan statistik deskriptif terhadap skor hasil belajar IPA kelompok kontrol menunjukkan ratarata $($ mean $)=16,01 ;$ median $(\mathrm{Me})=15,62 ;$ modus $(\mathrm{Mo})=14,84 ;$ varians $\left(\mathrm{s}^{2}\right)=6,98 ;$ dan standar deviasi $(\mathrm{s})=2,64$. berikut.

Data skor hasil belajar IPA kelompok kontrol disajikan dalam histogram seperti pada gambar 2

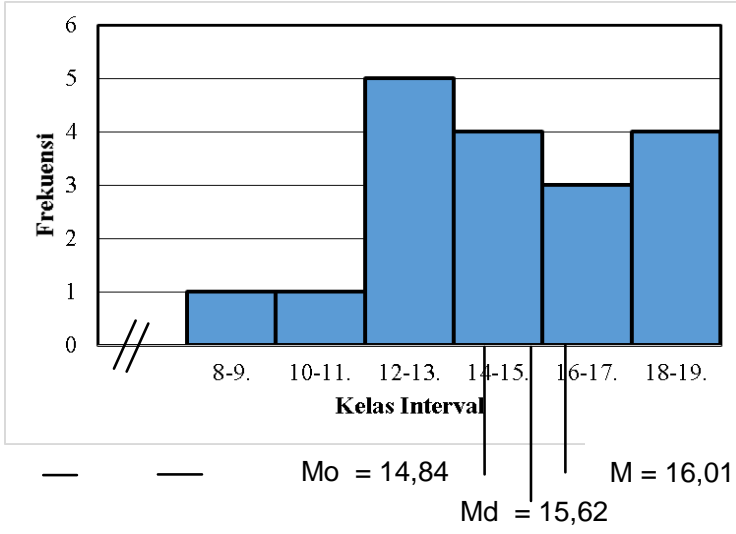

Gambar 2. Histogram Data Hasil Belajar IPA Kelompok Kontrol

Gambar histogram data hasil belajar IPA kelompok kontrol di atas menunjukkan bahwa Mo $<$ Md $<$ M. Kualitas variabel hasil belajar IPA kelompok ekperimen dapat diketahui dengan mengkonversikan skor rata-rata menggunakan skala penilaian acuan ideal teoretik. Berdasarkan hasil konversi, diperoleh bahwa skor rata-rata hasil belajar IPA kelompok kontrol dengan $M=16,01$ tergolong kriteria cukup.

Setelah menghitung data hasil belajar IPA pada masing-masing kelompok menggunakan statistik deskriptif, selanjutnya dilakukan pengujian prasyarat terhadap sebaran data yang meliputi uji normalitas dan uji homogenitas terhadap data hasil belajar IPA siswa. Uji normalitas data hasil belajar IPA dihitung menggunakan uji chi kuadrat $\left(\mathrm{X}^{2}\right)$ dengan kriteria pengujian data berdistribusi normal jika $X^{2}$ hitung $<X^{2}$ tabel, pada taraf signifikansi 5\% dengan $\mathrm{dk}=$ (jumlah kelas interval - parameter -1$)$.

Berdasarkan hasil perhitungan, diperoleh $X^{2}$ hitung hasil belajar IPA kelompok eksperimen sebesar 2,552 dan $X^{2}$ tabel dengan $\mathrm{dk}=2$ pada taraf signifikansi $5 \%$ adalah 5,591. Hasil hitung tersebut menunjukkan bahwa $X^{2}$ hitung hasil belajar IPA kelompok eksperimen lebih kecil dari pada $X^{2}$ tabel $(2,552<$ 5,591), sehingga data hasil belajar IPA kelompok eksperimen berdistribusi normal. Sedangkan, $X^{2}$ hitung hasil belajar IPA kelompok kontrol adalah 5,691 dan $X^{2}$ tabel dengan $\mathrm{dk}=3$ pada taraf signifikansi 5\% adalah 7,815. Hasil hitung tersebut menunjukkan bahwa $X^{2}$ hitung hasil belajar IPA kelompok kontrol lebih kecil dari pada $X^{2}$ tabel $(5,691<7,815)$, sehingga data hasil belajar IPA kelompok kontrol berdistribusi normal.

Setelah melakukan uji normalitas, selanjutnya dilakukan uji homogenitas. Uji homogenitas data hasil belajar IPA dihitung menggunakan uji $\mathrm{F}$ dengan kriteria data homogen jika $\mathrm{F}_{\text {hitung }}<\mathrm{F}_{\text {tabel. }}$. Berdasarkan hasil perhitungan, diketahui $\mathrm{F}_{\text {hitung }}$ hasil belajar IPA kelompok eksperimen dan kelompok kontrol adalah 1,83. Sedangkan $F_{\text {tabel }}$ dengan $d b_{\text {pembilang }}=22, d b_{\text {penyebut }}=33$, dan taraf signifikansi $5 \%$ adalah 1,91 . Hal ini menunjukkan bahwa $F_{\text {hitung }}<F_{\text {tabel }}(1,83<1,91)$ sehingga varians data hasil belajar IPA kelompok eksperimen dan kelompok kontrol adalah homogen.

Hasil uji prasyarat analisis menunjukkan bahwa sebaran data hasil belajar IPA kelompok eksperimen dan kelompok kontrol berdistribusi normal serta memiliki varians yang homogen. Sesuai dengan hasil perhitungan tersebut, maka dilanjutkan dengan pengujian hipotesis penelitian dengan menggunakan uji-t sampel independent (tidak berkorelasi) dengan rumus polled varians. Kriteria pengujian uji-t, yaitu $\mathrm{H}_{0}$ diterima jika $t_{\text {hitung }} \leq \mathrm{t}_{\mathrm{tab}}$ dan $\mathrm{H}_{0}$ ditolak jika $\mathrm{t}_{\text {hitung }}>\mathrm{t}_{\mathrm{tab}}$ pada taraf signifikansi $5 \%$ dengan $d b=n_{1}+n_{2}-2$. Rangkuman hasil analisis uji-t disajikan pada tabel 3 berikut. 
Tabel 3. Rangkuman Hasil Analisis Uji-t

\begin{tabular}{ccccccc}
\hline Kelompok & $\mathrm{n}$ & $\mathrm{Db}$ & Mean $(\bar{x})$ & $\mathrm{s}^{2}$ & $\mathrm{t}_{\text {hitung }}$ & $\mathrm{t}_{\text {tabel }}$ \\
\hline Eksperimen & 22 & 53 & 23,13 & 12,79 & 8,57 & 2,005 \\
Kontrol & 33 & & 16,01 & 6,98 & & \\
\hline
\end{tabular}

Tabel rangkuman hasil analisis uji-t di atas menunjukkan bahwa $t_{\text {hitung }}=8,57$ dan $t_{\text {tabel }}=2,005$ untuk $d b=n_{1}+n_{2}-2=53$ dengan taraf signifikansi $5 \%$. Berdasarkan kriteria pengujian, karena $t_{\text {hitung }}>$ $\mathrm{t}_{\text {tabel }}$ maka $\mathrm{H}_{0}$ ditolak dan $\mathrm{H}_{1}$ diterima. Artinya, terdapat pengaruh model pembelajaran snowball throwing berbasis penilaian kinerja terhadap hasil belajar IPA siswa kelas IV di SD Gugus 1 Kecamatan Sukasada Kabupaten Buleleng Tahun Pelajaran 2017/2018.

Hasil analisis data menunjukkan bahwa model pembelajaran snowball throwing berbasis penilaian kinerja berpengaruh terhadap hasil belajar IPA siswa kelas IV di SD Gugus 1 Kecamatan Sukasada Kabupaten Buleleng Tahun Pelajaran 2017/2018. Tingginya hasil belajar pada siswa kelompok eksperimen yang dibelajarkan dengan model pembelajaran snowball throwing berbasis penilaian kinerja disebabkan oleh beberapa faktor sebagai berikut.

Faktor pertama yaitu terjadinya proses pengolahan informasi oleh siswa. Alur pengolahan informasi yaitu (1) penyampaian informasi oleh guru kepada ketua kelompok, (2) penyampaian informasi oleh ketua kelompok kepada anggota kelompok, serta (3) pendalaman informasi melalui diskusi kelompok. Guru bertugas menyampaikan informasi kepada ketua kelompok, sedangkan ketua kelompok bertugas mencatat serta memahami informasi tersebut. Setelah guru menyampaikan informasi, ketua kelompok menyampaikan informasi tersebut kepada anggota kelompoknya dan dilanjutkan dengan diskusi kelompok. Pada diskusi kelompok, terjadi pendalaman informasi. Semua anggota bekerjasama dalam mendiskusikan, memahami, serta mengaitkan informasi yang diperoleh dengan lingkungan sekitarnya sehingga diperoleh kesimpulan. Melalui kegiatan tersebut, siswa dilatih untuk mengembangkan keterampilan menyimpulkan informasi yang diperolehnya. Hal tersebut sesuai dengan pendapat Kurniasih dan Sani (2016:77) yang menyatakan bahwa model pembelajaran snowball trowing memberikan pengalaman kepada siswa untuk mengembangkan keterampilan menyimpulkan isi berita atau informasi yang mereka peroleh dalam konteks nyata dan situasi yang kompleks.

Faktor kedua, siswa dapat menyampaikan permasalahan mengenai materi pelajaran yang belum dipahaminya dalam suasana belajar yang menyenangkan. Siswa diberi kesempatan untuk menuliskan permasalahan pada selembar kertas kerja yang nantinya diremas sehingga membentuk bola salju pertanyaan. Selanjutnya, bola salju pertanyaan tersebut dilemparkan pada siswa lain untuk dijawab. Penggunaan bola salju pertanyaan memberikan dampak positif bagi siswa. Dampak positif tersebut antara lain, suasana belajar menjadi lebih menyenangkan, siswa tidak merasa ragu dalam menyampaikan permasalahan mengenai materi pelajaran yang belum dipahaminya, dan siswa memperoleh jawaban berdasarkan permasalahan yang ditulis dalam bola salju pertanyaan. Hal tersebut sesuai dengan pendapat Shoimin (2014:174) yang menyatakan bahwa melalui penerapan model pembelajaran snowball trowing siswa dapat menyampaikan pertanyaan atau permasalahannya dalam bentuk tertulis yang nantinya akan didiskusikan bersama. Dengan demikian siswa dapat mengungkapkan kesulitan-kesulitan yang dialaminya dalam memahami materi pelajaran.

Faktor ketiga, penggunaan penilaian kinerja dalam pembelajaran. Penilaian kinerja membuat siswa menjadi lebih aktif selama proses pembelajaran. Hal tersebut ditunjukkan dengan peran aktif siswa selama mendiskusikan materi pelajaran dan tugas, keantusiasan dalam menyampaikan pertanyaan dan jawaban, serta keantusiasan dan kepercayaan diri pada saat mengkomunikasikan jawaban yang ditulisnya. Hal tersebut sesuai dengan pendapat Lai (dalam Marhaeni, 2017) yang menyatakan bahwa, penilaian kinerja dapat menjadi sebuah proses yang lebih memotivasi siswa, karena siswa menjadi lebih terlibat secara aktif di dalam kelas. Selain itu, penilaian kinerja memudahkan guru dalam menilai hasil belajar siswa secara proses dan produk, sehingga guru dapat mengetahui ketercapaian tujuan pembelajaran secara menyeluruh. Hal tersebut sesuai dengan pendapat Oktaviani (2014) yang menyatakan bahwa penilaian kinerja memudahkan guru dalam menilai proses dan tidak hanya hasil. Ketika siswa diminta mengerjakan sesuatu, maka guru bisa menilai proses kerja siswa sebaik menilai hasil kerja siswa.

Faktor keempat, pemberian penghargaan berupa kartu nilai kinerja. Penghargaan tersebut diberikan berdasarkan kinerja siswa selama proses pembelajaran. Pemberian penghargaan dengan kartu nilai kinerja membuat antusias belajar siswa menjadi meningkat. Keantusiasan tersebut terlihat pada saat siswa mendiskusikan materi pelajaran serta tugas bersama anggota kelompoknya, menuliskan 
pertanyaan dan jawaban, serta mengkomunikasikan jawaban yang dituliskan. Siswa berlomba-lomba untuk menunjukkan kinerja yang baik selama proses pembelajaran agar mendapatkan nilai yang bagus pada kartu nilai kinerjanya. Pemberian penghargaan tersebut memacu peningkatan motivasi belajar serta hasil belajar siswa pada setiap pembelajaran. Hal tersebut senada dengan hasil penelitian Sujiantari (2016) yang menunjukkan bahwa pemberian penghargaan memberikan pengaruh yang positif terhadap motivasi belajar siswa. Lebih lanjut, Suardika (2014) juga menyatakan pemberian penghargaan dapat menimbulkan rasa bangga pada siswa, sehingga mendorong siswa untuk melakukan kegiatan serta hasil belajar yang lebih baik dari sebelumnya.

Berbeda halnya pada kelompok kontrol yang dibelajarkan dengan model pembelajaran konvensional. Pembelajaran pada kelompok ini masih berpusat pada guru. Guru menjadi sumber belajar utama di kelas dan bertugas mentransfer pengetahuannya kepada siswa melalui kegiatan ceramah. Tugas siswa hanya mendengar, mencatat, dan menghapal. Pada saat guru menanyakan tentang materi yang telah dijelaskan pun, hanya beberapa siswa saja yang aktif menjawab. Kegiatan pembelajaran yang seperti ini menyebabkan siswa menjadi bosan sehingga terkadang membuat keributan ketika proses pembelajaran sedang berlangsung. Hal tersebut sesuai dengan pendapat Sulaeman (dalam Rasana, 2009:18) yang menyatakan bahwa pembelajaran konvensional merupakan metode yang paling efisien dalam mengajar yang bersifat hafalan (ingatan). Hal ini menunjukkan bahwa ceramah mendominasi kegiatan belajar mengajar yang menekankan hafalan tersebut. Proses belajar mengajar yang menekankan pada hafalan menyebabkan proses belajar menjadi kurang bermakna sehingga berpengaruh terhadap rendahnya hasil belajar siswa.

Temuan dalam penelitian ini didukung oleh beberapa hasil penelitian yang dilakukan oleh peneliti terdahulu. Aniati (2016) membuktikan bahwa model pembelajaran snowball throwing membuat siswa bergembira, semangat, dan aktif saat mengikuti kegiatan pembelajaran sehingga berdampak positif terhadap hasil belajar IPA siswa. Penelitian yang serupa juga dilakukan oleh Wahyuningsih (2017) yang membuktikan bahwa model pembelajaran snowball throwing membuat siswa termotivasi untuk belajar yang ditunjukkan dengan peningkatan intensitas pemberian tanggapan, baik berupa sanggahan ataupun pendapat dalam proses pembelajaran. Selain itu, hasil penelitian menunjukkan bahwa hasil belajar IPA siswa cenderung memeroleh nilai yang tinggi. Selanjutnya, Dewi (2016) membuktikan bahwa penggunaan asesmen (penilaian) kinerja memberikan pengaruh positif yang ditandai dengan keterlibatan siswa secara aktif dalam setiap fase-fase pembelajaran sehingga berdampak pada peningkatan hasil belajar IPA.

Berdasarkan hasil yang diperoleh selama penelitian yang kemudian didukung oleh beberapa hasil penelitian terdahulu, dapat diketahui bahwa hasil belajar kelompok siswa yang dibelajarkan dengan model pembelajaran snowball throwing berbasis penilaian kinerja lebih unggul daripada kelompok siswa yang dibelajarkan dengan model pembelajaran konvensional.

\section{Simpulan dan Saran}

Berdasarkan hasil penelitian dan pembahasan, dapat disimpulkan bahwa terdapat pengaruh model pembelajaran snowball throwing berbasis penilaian kinerja terhadap hasil belajar IPA siswa kelas IV di SD gugus 1 Kecamatan Sukasada Kabupaten Buleleng Tahun Pelajaran 2017/2018. Hasil tersebut diperoleh dari rumus uji-t polled varians, dengan $t_{\text {hitung }}=8,57$ dan $t_{\text {tabel }}=2,005$ untuk db $=n_{1}+n_{2}-2=53$ (pada taraf signifikansi 5\%). Hal ini berarti $t_{\text {hitung }}>\mathrm{t}_{\text {tabel, }}$, sehingga $\mathrm{H}_{0}$ ditolak dan $\mathrm{H}_{1}$ diterima. Berdasarkan ratarata hitung, diketahui rata-rata kelompok eksperimen adalah 23,13 dan rata-rata kelompok kontrol adalah 16,01. Hal tersebut menandakan adanya perbedaan hasil belajar IPA antara kelompok eksperimen dan kelompok kontrol yang ditandai dengan lebih tingginya mean kelompok eksperimen dari pada kelompok kontrol.

Saran yang dapat disampaikan berdasarkan penelitian yang telah dilakukan adalah sebagai berikut. Pertama, disarankan kepada siswa agar terlibat secara aktif dan menunjukkan kinerja yang baik selama proses pembelajaran. Kedua, disarankan kepada guru untuk menggunakan model pembelajaran snowball throwing berbasis penilaian kinerja sebagai alternatif untuk mewujudkan proses pembelajaran yang interaktif, menyenangkan, berbasis proses dan produk, serta meningkatkan hasil belajar siswa. Ketiga, disarankan kepada kepala sekolah agar hasil penelitian ini dijadikan pedoman dalam mengambil kebijaksanaan tentang proses pembelajaran di sekolah yang dipimpinnya. Keempat, disarankan kepada peneliti lain untuk melakukan penelitian tentang model pembelajaran snowball throwing berbasis penilaian kinerja pada mata pelajaran IPA maupun mata pelajaran lain dengan memperhatikan kendalakendala yang dialami dalam penelitian ini sebagai bahan pertimbangan untuk perbaikan dan penyempurnaan dalam penelitian selanjutnya. 


\section{Daftar Rujukan}

Agung, A. A. G. 2014. Buku Ajar Metodologi Pendidikan. Yogyakarta: Aditya Media Publishing.

Agustiana, I Gusti Ayu Tri dan I Nyoman Tika. 2013. Konsep Dasar IPA Aspek Fisika dan Kimia. Yogyakarta: Penerbit Ombak.

Arhin, Ato Kwamina. 2015. "The Effect of Performance Assessment Driven Instruction on the Attitude and Achievement of Senior High School Students in Matematics in Cape Coast Metropolis, Ghana". Tersedia pada https://files.eric.ed.gov/fulltext/EJ1083838.pdf (diakses tanggal 05 Januari 2018).

Dewi, Gusti Ayu Made Taria. 2016. "Penerapan Model Problem Based Learning Berbantuan Asesmen Kinerja Untuk Meningkatkan Hasil Belajar IPA". Tersedia pada https://ejournal.undiksha.ac.id/index.php/JJPGSD/article/viewFile/7264/4962 (diakses tanggal 07 Desember 2017).

Fazet,Friske dan I Gusti Putu Asto. 2013. Aplikasi Model Pembelajaran CTL Menggunakan Metode Snowball Throwing Dengan Standar Kompetensi Dasar Teknik Digital Terhadap Hasil Belajar Siswa. Jurnal Pendidikan Teknik Elektro, Jurnal Pendidikan Teknik Elektro, Vol.2, No.3.

Hafid R Hakim, Abdul R. 2013. Pengaruh Perpaduan Metode Pembelajaran Snowball Throwing Dengan Talking Stick Terhadap Hasil Belajar Siswa Pada Standar Kompetensi Menerapkan Dasar-Dasar Elektronika. Jurnal Pendidikan Teknik Elektro, Vol.2, No.1.

Husien, Latifah. 2017. Profesi Keguruan Menjadi Guru Profesional. Yogyakarta: Pustaka Baru Press.

Herrmann, Kim J. 2013. "The Impact of Cooperative Learning on Student Engagement: Result From an Intervention". Tersedia pada http://journals.sagepub.com/doi/10.1177/1469787413498035 (dikases tanggal 12 Maret 2018).

Kurniasih, Imas dan Berlin Sani. 2016. Ragam Pengembangan Model Pembelajaran untuk Meningkatkan Profesionalitas Guru. Cet ke-3. Kata Pena.

Marhaeni, A. A. I. N., dkk. 2017. Asesmen Autentik dalam Pembelajaran Bahasa Inggris. Depok: PT Rajagrafindo Persada.

Oktaviani, L. 2014. "Pengaruh Model Problem Based Learning Berbasis Asesmen Kinerja Terhadap Hasil Belajar IPA". Tersedia pada http://download.portalgaruda.org/article.php?article=258500\&val=7028\&title=pengaruh model problem based learning berbasis asesmen kinerja terhadap hasil belajar ipa ditinjau dari gaya kognitif (diakses tanggal 25 Desember 2017).

Rahma, Abd. 2017. Penerapan Metode Snowball Throwing Untuk Meningkatkan Hasil Belajar IPS Siswa Kelas V Pada SDN No. 1 Pantolobete. Jurnal Kreatif Tadulako Online, Vol. 5, No.4.

Shoimin, Aris. 2014. 68 Model Pembelajaran Inovatif dalam Kurikulum 2013. Yogyakarta: Ar-Ruzz Media.

Sialagan, Ardin dan Irmayanti. 2011. Penerapan Model Pembelajaran Snowball Throwing Dalam Meningkatkan Hasil Belajar Siswa (Studi Kasus SMA Negeri 1 Bintang Bayu Kabupaten Serdang Bedagai). Jurnal Geografi, Vol.3, No.1.

Suardika, I Putu. 2014. "Penerapan Model Pembelajaran Snowball Throwing Berbantuan Media Lingkungan untuk Meningkatkan Aktivitas dan Hasil Belajar IPA Siswa Kelas III SD". Tersedia pada https://ejournal.undiksha.ac.id/index.php/JJPGSD/article/viewFile/3874/3100 (diakses tanggal 11 Mei 2018).

Sujiantari, Kadek. 2016. "Pengaruh Reward dan Punishment Terhadap Motivasi Belajar Siswa dalam Pembelajaran IPS (Studi pada SMP Negeri 1 Singaraja Kelas VIII Tahun Ajaran 2015/2016)". 
Tersedia pada https://ejournal.undiksha.ac.id/index.php/JJPE/article/viewFile/7573/5171 (diakses tanggap 11 Mei 2018)

Sukardjo, M. dan Ukim Komarudin. 2013. Landasan Pendidikan Konsep dan Aplikasinya. Jakarta: PT RajaGrafindo Persada.

Susanto, Ahmad. 2016. Teori Belajar dan Pembelajaran di Sekolah Dasar. Cet ke-4. Jakarta: Prenadamedia Group.

Tim MKDP. 2013. Kurikulum dan Pembelajaran. Cet ke-3. Jakarta: Rajawali Press.

Undang-Undang No 20 Tahun 2003 tentang Sistem Pendidikan Nasional.

Wahyuningsih, Sri Wida. 2017. "Pengaruh Model Pembelajaran Kooperatif Tipe Snowball Throwing Terhadap Hasil Belajar IPA Siswa Kelas V SDN 1 Sangsit Buleleng". Tersedia pada https://ejournal.undiksha.ac.id/index.php/JJPGSD/article/view/10984/7037 (dikases tanggal 23 Desember 2017).

Widiana, I Wayan. 2016. "Pengembangan Asesmen Proyek dalam Pembelajaran IPA di Sekolah Dasar". Tersedia pada http://e-journal.unipma.ac.id/index.php/PE/article/view/50/47 (diakses tanggal 09 Maret 2018).

Wirawan, Rahmat. 2014. "Increasing Vocabulary Mastery of The Seventh Grade Students Through Snowball Throwing". Tersedia pada http://jurnal.untad.ac.id/jurnal/index.php/ELTS/article/view/2131/1354 (dikases tanggal 23 Desember 2017). 